\title{
United States and the Middle East after the Cold War
}

\author{
Yusuf Ibrahim Gamawa ${ }^{1}$ \\ ${ }^{1}$ Department of Political Science,Bauchi State University Gadau,Bauchi State,Nigeria \\ Correspondence: Yusuf Ibrahim Gamawa, Department of Political Science,Bauchi State University Gadau,Bauchi \\ State,Nigeria.Email: yusufgamawa@ymail.com \\ To cite this article: Gamawa, Y. I. (2018).United States and the Middle East after the Cold War. American Finance \\ \& Banking Review, 3(1), 1-4. Retrieved from http://www.cribfb.com/journal/index.php/amfbr/article/view/135
}

Received: September 1, 2018

Accepted: September 5, 2018

Online Published: September 13, 2018

\begin{abstract}
The United States emerged as the most powerful country after World War II and as such found itself in an influential position to be involved in the future and destinies of many countries across the globe. The U.S. played a major role in the post War economic reconstruction in Europe and rendered assistance to many European states. American power at this time was seen to have extended to other parts of the globe, including the Middle East, which has been a region of interest to outside powers. This short paper tries to look at U.S. ambitions in the region and how far the U.S. has gone in achieving these ambitions. The paper argues that U.S. policies in the Middle East were in the long run, a failure, despite whatever successes achieved, following certain developments in the region, beginning with the 1979 revolution in Iran.
\end{abstract}

Keywords: U.S., Middle East, Cold War, Power, Policies.

The system of World Order was established after World War I. At that time the United States was in a position of power without historical precedent. It had about fifty percent of the world's wealth and a position of remarkable security, political and economic elites were aware of this facts, and not surprisingly, set about to organize a world system favorable to their interests. Extensive plans were developed for what was called "Grand Area" a world system in which US interests would be expected to flourish. The plans extended to all major areas and issues, and were to a large extent implemented in the early Post War years. Plans for the Middle East were developed within this context. The major concern is the incomparable energy reserves of the region; these were to be incorporated within the US dominated system. As in Latin America, it was necessary to displace the French and British interests and establish US control over what the state department described as "stupendous source of strategic power and one of the greatest material prizes in world history", probably the richest economic prize in the world in the field of foreign investment. President Eisenhower described the Middle East as the most strategically important area in the world" [Chomsky, 1991].

The U.S. found its control or influence in the Middle East extremely necessary, and was ready to practically follow up with its world order plan. Initial concerns apart from oil, were Israel, and containing Soviet influence in the region. The United states at the beginning was skeptical about supporting a Jewish state in the Middle East, and that time considered supporting such a venture as futile, and tended to see Israel as more of a political liability, Kermit Roosevelt was quoted in a famous article carried in the Middle East Journal as saying "All Americans with Diplomatic, education, missionary, or business experience in the Middle East protest fervently protest that support of political Zionism is directly contrary to our national interests, as well as to common justice" [Hudson, 1996]. It was much after that Israel began to appear as an asset to the United States, and as a result began to enjoy total political/ diplomatic as well economic support from the United States. It was a support which from the beginning, 
especially during the Cold War days, was to make American policy in the region appear difficult to succeed, the support for the Jewish state was constantly be exploited by the Soviets, who also were interested in the oil resources in the region, and naturally became the rivals of the United States, and pursued a policy of promoting Arab nationalism and support for the Palestinian, which is diametrically opposed to the American stand in the region.

At this time the Americans had succeeded in replacing the British, and to an extent the French influence and control especially in the oil industry, but faced a challenge from the Soviets. More than half of US oil imports came from the Middle East, and the soviets influence on oil pricing was a major source of concern for the US, for this the US was determined to make sure that Soviet expansion in the region is contained. The United States was heavily dependent on Middle Eastern oil for its domestic consumption, considering the level of industrial growth in the country, it was natural that demand of energy would be enormous, and the US was ready to take care of the future of its energy supplies at all cost. Special attention was focused on countries such as Saudi Arabia, Kuwait, Iran and Iraq in the region by the United States, and the US became involved in an operation that returned Shah Reza Pahlavi to Power in 1953 [Hudson, 1996]. In the long run it succeeded in dealing with the Soviet threat, after the Soviets invaded Afghanistan, and the US was involved in helping indigenous groups put the Soviets out of their Territory, all in an effort to ensure complete access and control over the Middle East oil.

However dramatic changes began to take place, which were to have a profound effect on the relations between the US and the Middle East, and this was the Iranian revolution of 1979, led by Imam Khomeini. The revolution overthrew the Shah regime which had previously enjoyed American support and cooperation. Prior to the revolution, American influence in the region was almost absolute, and it appeared to be in control of the entire Middle East oil resources of all countries including Saudi Arabia, Kuwait, Qatar, Iraq, Oman, UAE, Bahrain and Iran. The new Iranian regime came up with anti imperialist policies that were hostile to the United States and its twin interests in the region, namely; Oil and Israel, and so this became a major source of concern and the United States was forced to review its policy in the region. The regime change in Iran made Iraq -US relations stronger in the region, and soon Iraq became engaged in a war with Iran that lasted for eight years, but which the Iranians eventually won. This is despite open American support to Iraq, as well as support from other Arab nations, who expressed concerns about Iran's aggressive tendencies, and became worried about their security.

At the end of the Cold War in 1990, the United States continued to pursue it policy of containing Iran, which it started since the 1979 revolution. It feared the Iranian policy of exporting the revolution to other Arab Islamic countries in the region. The US at this time had consolidated its power base in the region by establishing military bases in most of the friendly countries in the region that also felt threatened by the Khomeini regime. The bases were to give the US a permanent presence in the region, as well as to confront Iran [Thayer, 2003]. But while the US was pursuing its policy towards Iran, Saddam Hussein had grown powerful, and was to exploit relations with other Arab nations to champion and Arab cause and the region, and at the same time began to threaten other neighboring Arab countries which were of lesser power to Iraq. Saddam's aggressive behavior had been noted by the United States, and the US carefully adjusted to his style [ R.K. Herrman, 1991]. But at this time Saddam's threats against Israel served as deterrents to US, and generally the containment policy of Iran continued to remain the focus of the United States, and as such Saddam's excesses were overlooked by American policy makers, as a matter of policy, the US could not possible do anything that could weaken Iraq, because to do so was seen as indirectly helping Iran. Washington could not deter Saddam from invading Kuwait, even when it could, US officials visiting Baghdad in 1990 spelled out American concerns over about Iraq's aggressive and hostile behavior. The US could not take a position on the exact terms of settlement on the territorial and economic disputes between Iraq and Kuwait. Saddam may have believed that American interests were not sufficiently threatened to evoke massive military response, and concluded that Kuwait could be taken without any war [ R.K. Herrman, 1991]. But the invasion of Kuwait by Saddam Hussein marked the beginning of the Gulf War in 1991. It was only after several efforts have failed to convince Saddam to withdraw from Kuwait that the United Nations issued a resolution for military action which was carried out the Allied forces under the leadership of the United States, and Saddam was forced to withdraw from Kuwait. Since the Gulf War Washington maintained a close watch on the Middle East, mean while Saddam retreated quietly. But the Gulf War remain significant in the history of American relations with the Middle East, in the sense that it was the first time the US led a direct military attack on country in the region.

Another significant event in the post Cold War era that was to change the course of international relations in the Middle East was the September 9/11 attacks on the twin towers of the United States i.e. the attack on the world trade centre, which was carried out by Al-Qaida, a terrorist organization headed by Osama Bin Laden. Al-Qaida seemed 
to have inspired anti- American militants' worldwide and Iraq served as a training ground for new jihadists [J. Pressman, 2009]. In the aftermath of the attacks, the Bush administration responded by crafting three major policies to advance US National Security interests in the region; defeat terrorism, promotion of democracy, and stopping the development of weapons of mass destruction, these policies were delineated and defended in the administration's 2002 National Security Strategy, major Presidential addresses and other official speeches [J. Pressman, 2009]. Nine days after the 9/11 attacks the Bush Administration declared the War on Terror and concluded that the war will not end until all terrorist groups of global reach have been found, stopped and defeated. The administration of Bush was also worried about the alliance of terrorist organizations and the various countries in which they were based and as a consequence President Bush pledged to pursue nations that provide aid or safe haven to terrorism [J. Pressman, 2009]. And as a result Afghanistan, Al-Qaida's home became a potential target, the United States invaded Afghanistan and toppled the Taliban regime, took control of Kabul and put a peace keeping force in place.

The United States having succeeded in taking over Afghanistan, now pursued its second policy of stopping the proliferation of weapons of mass destruction which will followed by the spread of democracy. Earlier on, the Bush administration had identified the countries of North Korea, Iran and Iraq as belonging to the axis of evil, as countries arming to threaten the peace of world. Bush was quoted in a speech as saying "By seeking weapons of mass destruction, these regimes pose a grave and growing danger" [J. Pressman, 2009]. American concerns about terrorism and weapons of mass destruction became intertwined, and Bush was quoted as saying "Terror cells and outlaw regimes building weapons of mass destruction are different faces of the same evil, our security requires that we confront both". Thus the US under the pretext of WMD invaded Iraq and toppled the regime of Saddam Hussein despite the disapproval of the United Nations in 2003, and took over the affairs of the country, stationed a military force in Baghdad. In Post Cold War America, the foreign policy establishment shifted, with no other threat like that of the Soviet during the Cold War, and so the 9/11 attacks became the dominant issue in US foreign policy overshadowing all other international issues. It led to a fundamental policy reorientation; significant spending increases; bureaucratic changes wars in Afghanistan and Iraq; and the deployment of U.S. military forces in many new places.

In conclusion, Fareed Mohammedi and Yahya Sadowski, in their article titled "Shaky Foundations" maintained that "The Bush team's initiatives rest on a common vision of the U.S. position in the world and embody one style of diplomacy. They assume that the structure of international politics is now unipolar, with US occupying position of sole hyper power. There may be other powers in the world, but none of them can individually resist Washington, much less actually threaten it. Thus the Bush White House thinks, it makes sense for the US to adopt a unilateral diplomatic style. Washington should mobilize the world community when that is amenable to the national interest, and ignore or override world opinion when it is not. Where the US leads, U.S. allies and rivals must follow. George W. and his team view this situation as benign: they believe that America not only has unique powers but that it possesses the wisdom and charity necessary to exercise them in the global interest." [Mohammed, Sadowski, 2001] Despite all that has been said the US policy in the Middle East after the Cold War has been described by many analysts as a failure. The Bush administration's policy did not make any significant progress on any of the three policies, the benefits were more limited than expected; the costs higher than anticipated; and the damage in terms of national security and international relationship was to both the United states and its allies [J. Pressman, 2009].

\section{References}

Bahgat Korany, The Middle East Since Cold War: Torn between Geopolitics and Geoeconomics.

Bradley A. Thayer, The Pax Americana and the Middle East: US Grand Strategic Interests in the Region After September 11, THE Begin- Sadat Center for Strategic Studies, Bar-Ilan University, Middle East Security and Policy Studies No 56, 2003.

Fareed Mohamedi and Yahya Sadowski, Shaky Foundations: The Decline (But Not Fall) of US Hegemony in the Middle East, Middle East Report, 2001.

Gawdat Bahgat, American Oil Piplomacy in the Persian Gulf and the Caspian Sea, University Press Florida, 2010. Jeremy Pressman, Power Without Influence, The Bush Administration's Failure in the Middle East, International Security Vol 33, No 4, 2009.

Library of Congress, Country Studies. www.countrystudies.us/persiangulfstates

Marissa Allisson, US and Iranian Strategic Competion: Saudi Arabia and the Gulf States, Centre for Strategic and International Studies, Doha, 2010.

Michael Hudson, To Play The Hegemon: Fifty Years of U.S. Policy Towards the Middle East, Middle East Journal,Vol50,NO 3, 1996. 
Noam Chomsky, After the Cold War: US Policy in the Middle East, Cultural Critique, Vol 19, the Economies of War, 1991.

Pirouz Motjahed Zadeh, Security and Territoriality in the Persian Gulf, London, 1999.

Richard Herrmann, The Middle East and the New World Order: Rethinking U.S Political Strategy after the Gulf War, 1991.

Robert A. Pape, Soft Balancing against the United States, Research Gate, 2005

Stephen M. Walt, The end of the American Era, The National Interest, 2011

\section{Copyrights}

Copyright for this article is retained by the author(s), with first publication rights granted to the journal.

This is an open-access article distributed under the terms and conditions of the Creative Commons Attribution license (http://creativecommons.org/licenses/by/4.0/). 